\title{
Anthropometric Measurements in Toothed and Toothless Maxillaries and its Consequences in Human Alveolar Bone Resorption
}

\author{
Mediciones Antropométricas en Maxilares con y sin Dientes \\ de Humanos y sus Consecuencias en la Reabsorción Ósea Alveolar
}

\author{
"Jaciel Benedito de Oliveira; ${ }^{* *}$ Andrelle Nayara Cavalcanti Lima de Almeida; ${ }^{* * *}$ Carla Cabral dos Santos Accioly Lins; \\ ${ }^{* * *}$ Adelmar Afonso de Amorim Júnior \& ****Zélia Albuquerque Seixas
}

DE OLIVEIRA, J. B.; DE ALMEIDA, A. N. C. L.; LINS, C. C. S. A.; JÚNIOR, A. A. A. \& SEIXAS, Z. A. Anthropometric measurements in toothed and toothless maxillaries and its consequences in human alveolar bone resorption. Int. J. Morphol., 30(3):1173$1176,2012$.

SUMMARY: This study proposes to measure and compare anthropometric measurements between toothed and toothless maxillas. 26 human skulls were used with: 13 toothed and 13 toothless maxillas. The measurements were made between the distances of the alveolar ridge (AR): the anterior nasal spine (ANS), to the incisive foramen (FI) and the palatine foramen, greater (FPMA) and lower (FPME) on both sides by two evaluators. The data obtained showed that the average of the measurements were correspondingly higher in toothed maxillas than in toothless, for all measurements in any one of the evaluators. The AR-ANS $(p=0.001), I F-A R(p=0.006)$, AR-FPMA right $(p=0.001)$ and AR-FPMA left $(p<0.001)$ and AR-FPME on both sides $(p=0.001)$ demonstrating significant differences between the two types of maxilla. Thus we verify that, as the tooth loss occurs, irreversible anatomical changes take place in the maxilla bone, which must be taken into account in the design and manufacture of prostheses and osseointegrated implants.

KEY WORDS: Anatomy; Maxilla; Total prosthesis; Alveolar bone loss; Dental implantation.

\section{INTRODUCTION}

The growing number of elderly in the population has caused a significant increase in studies that propose to investigate the phenomena of human aging (Unfer et al., 2006). Within this context, the oral health has an important role, because there is a close relationship between aging and loss of teeth as the teeth of the elderly are exposed for a longer period to factors that lead to its loss, such as caries, periodontal disease, endodontic complications, trauma and iatrogenic dental treatment (Jorge et al., 2009; Ribeiro et al., 2009). In addition, there are systemic factors related to bone loss as low calcium intake, osteoporosis, hyperparathyroidism, hyperthyroidism, diabetes and the use of corticosteroids (Paganini-Hill, 2007; Jorge et al.).

In modern dentistry, the lack of bone in the alveolar ridges has been a major problem in aesthetic and functional recovery of patients who have suffered tooth loss (Marzola, 2008; Astudillo Silva, 2010). The vertical resorption of the maxilla is, on average, four times higher than that of the mandible, with an estimated average annual vertical bone resorption of $0.1 \mathrm{~mm}$ after tooth loss (Magini, 2006; Astudillo Silva).

Therefore, this study proposed to conduct an investigation of the anatomical changes that occur in the maxillary alveolar bone ridge after loss of teeth, measure and compare anthropometric measurements between toothed and toothless maxillas, checking for possible differences between them.

\section{MATERIAL AND METHOD}

It were used 26 human skulls, 13 toothed and 13 toothless maxillas, belonging to the Department of Human Anatomy of the Centre for Biological Sciences, Federal

* Graduated in Dentistry, Federal University of Pernambuco, Recife-PE, Brazil.

** Graduate Student Course in Dentistry, Federal University of Pernambuco, Recife-PE, Brazil.

**** $\mathrm{PhD}$ Professor of the Departament of Human Anatomy, Federal University of Pernambuco, Recife-PE, Brazil.

**** PhD Professor of the Departament of Prosthodontics and Oral-Facial Surgery, Federal University of Pernambuco, Recife-PE, Brazil. 


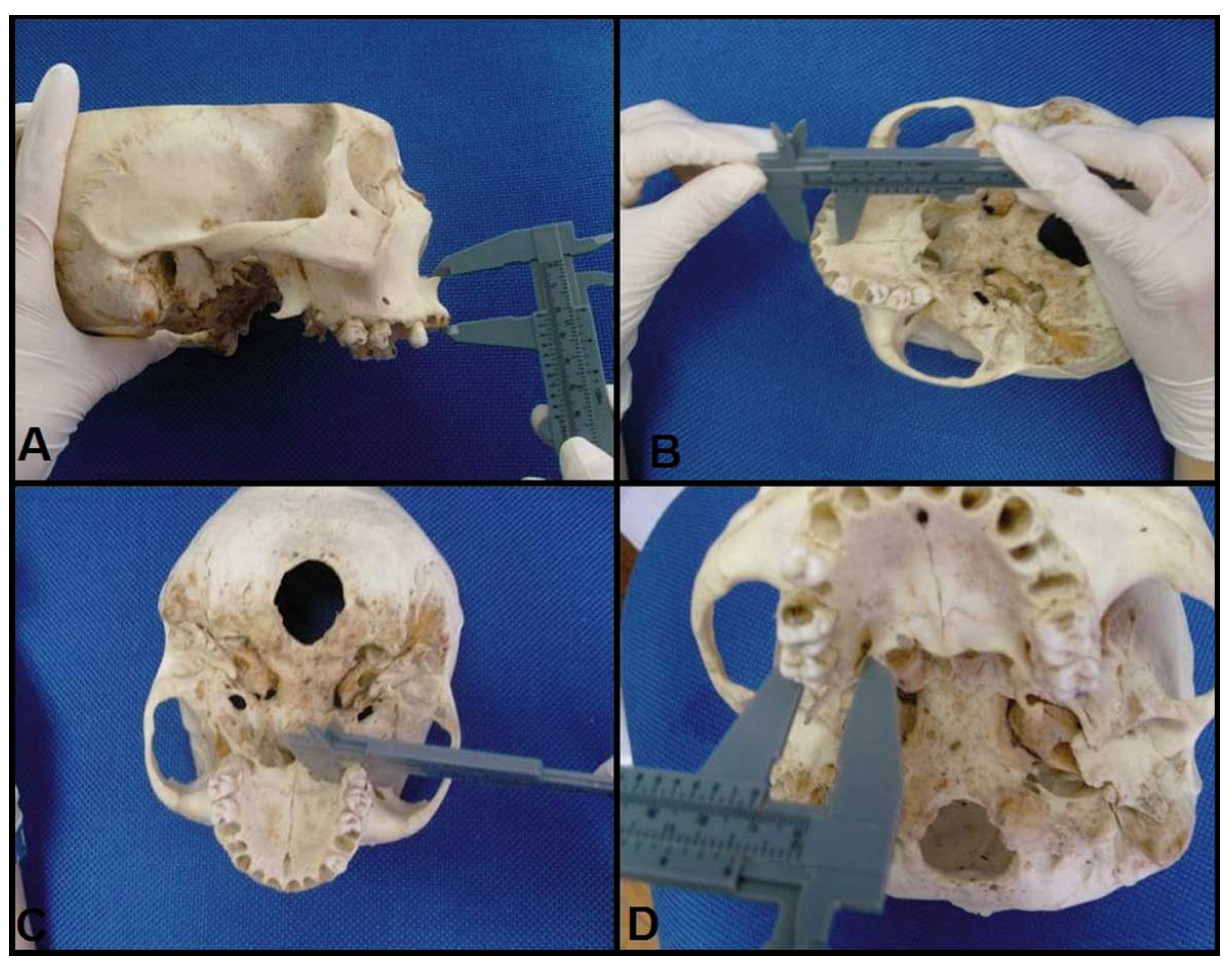

Fig. 1. Measurement of distances studied in toothed maxillas. A. Alveolar ridge (AR) to the anterior nasal spine (ANS), B. Alveolar ridge (AR) to the incisive foramen (IF), C. Alveolar ridge $(\mathrm{AR})$ to the greater palatine foramen (FPMA) and D. alveolar ridge (AR) to the lesser palatine foramen (FPME).

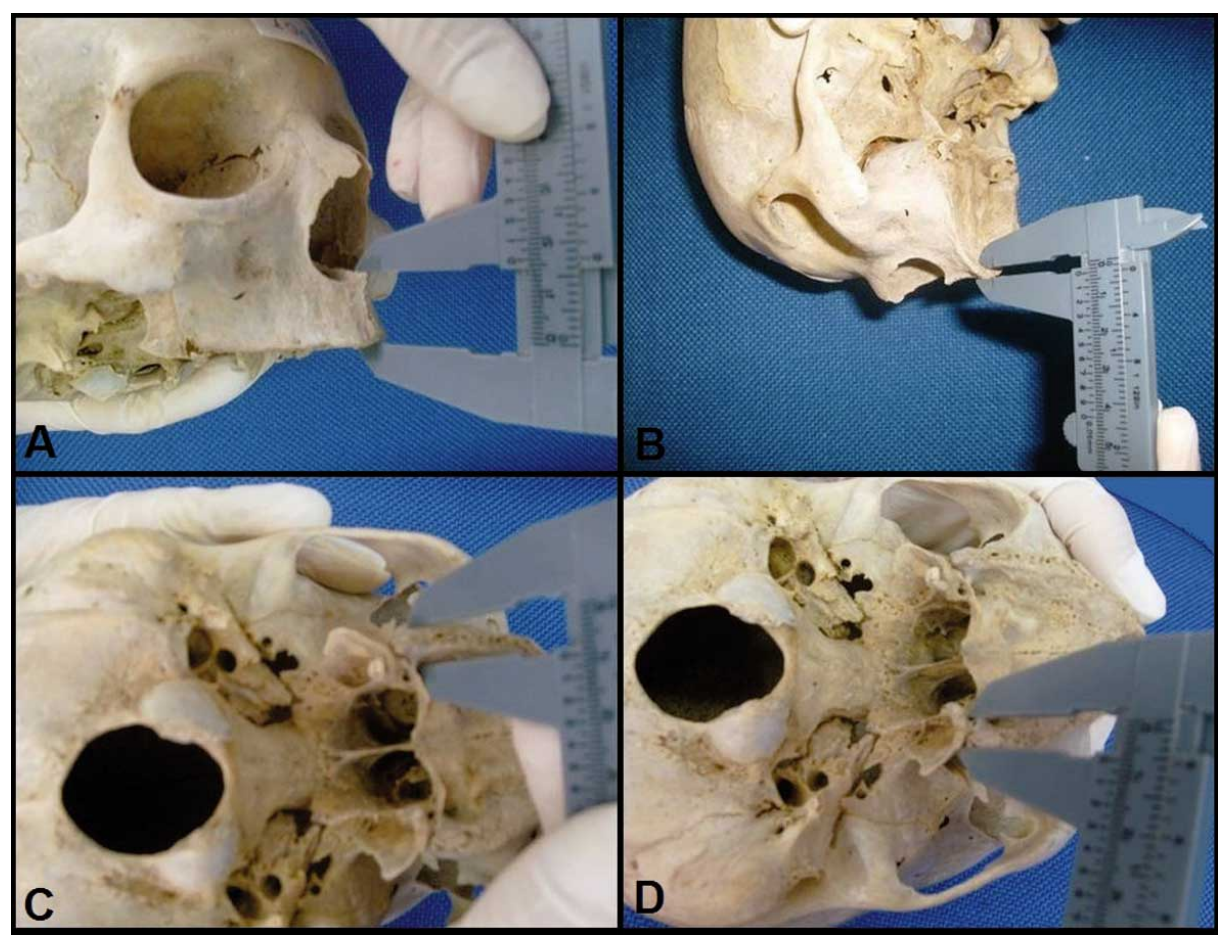

Fig. 2. Measurement of distances studied in toothless maxillas. A. Alveolar ridge (AR) to the anterior nasal spine (ANS), B. Alveolar ridge (AR) to the incisive foramen (IF), C. Alveolar ridge $(\mathrm{AR})$ to the greater palatine foramen (FPMA) and D. alveolar ridge (AR) to the lesser palatine foramen (FPME).
University of Pernambuco, Recife-PE, Brazil. The aspects of race, age and sex were not considered. The measurements were performed with calipers (accuracy $0.05 \mathrm{~mm}$ ) according to Mandarim-de-Lacerda (1995), between the distance of the crest of the alveolar ridge (AR): to the anterior nasal spine (ANS), to the incisive foramen (FI) and the palatine foramen, greater (FPMA) and lower (FPME) on both sides (right [R] and left [L]), by two evaluators so in toothed maxillas (Fig. 1), as in toothless maxillas (Fig. 2).

Data analysis was obtained from to the average, median, standard deviation, the concordance correlation coefficient with a confidence interval of $95.0 \%$. Data were entered into an Excel spreadsheet and statistical calculations were obtained using SPSS (Statistical Package for Social Sciences) version 13 and MED CALC in version 10.4.8.

\section{RESULTS}

With the measurements obtained from AR-ANS, IFAR, AR-FPMA-R, ARFPMA-L, AR-FPME-R and AR-FPME-L (Table I) it was observed that the averages were correspondingly more high in toothed maxillas, showing differences among the two types of maxilla. In the study of inter-examiner calibration was possible to verify high concordance correlation coefficient, with values greater than 0.94 . 
DE OLIVEIRA, J. B.; DE ALMEIDA, A. N. C. L.; LINS, C. C. S. A.; JÚNIOR, A. A. A. \& SEIXAS, Z. A. Anthropometric measurements in toothed and toothless maxillaries and its consequences in human alveolar bone resorption. Int. J. Morphol., 30(3):1173-1176, 2012.

Table I. Average of the distances of the anthropometric points in toothed and toothless maxillas.

\begin{tabular}{lcccc}
\hline \multirow{2}{*}{ Parameters } & Evaluators & Toothless & Toothed & \multirow{2}{*}{ P-Value } \\
\cline { 2 - 4 } & & Mean \pm SD & Mean \pm SD & \\
\hline \multirow{2}{*}{ AR-ANS } & 1 & $1.206 \pm 0.394$ & $1.849 \pm 0.353$ & $\mathrm{p}=0.001^{*}$ \\
\cline { 2 - 4 } AR-FI & 2 & $1.222 \pm 0.378$ & $1.870 \pm 0.349$ & $\mathrm{p}=0.001^{*}$ \\
\hline \multirow{2}{*}{ AR-FPMA-R } & 1 & $0.524 \pm 0.175$ & $0.819 \pm 0.260$ & $\mathrm{p}=0.006^{*}$ \\
\cline { 2 - 4 } AR-FPMA-L & 2 & $0.564 \pm 0.223$ & $0.818 \pm 0.263$ & $\mathrm{p}=0.07^{*}$ \\
\hline \multirow{2}{*}{ AR-FPME-R } & 1 & $0.996 \pm 0.216$ & $1.448 \pm 0.296$ & $\mathrm{p}=0.001^{*}$ \\
& 2 & $0.995 \pm 0.228$ & $1.454 \pm 0.289$ & $\mathrm{p}=0.001^{*}$ \\
\hline \multirow{2}{*}{ AR-FPME-L } & 1 & $1.012 \pm 0.254$ & $1.531 \pm 0.320$ & $\mathrm{p}=0.001^{*}$ \\
& 2 & $1.007 \pm 0.246$ & $1.519 \pm 0.372$ & $\mathrm{p}=0.001^{*}$ \\
\hline
\end{tabular}

*There was a significant difference between toothed and toothless maxillas.

\section{DISCUSSION}

The maxilla is a bone pair, short, symmetrical, with irregular shape, pneumatic and is in the center of the face, forming with the opposite side a bone complex called upper facial skeleton (Zanon, 2009; Astudillo Silva). Their average dimensions are $35 \times 35 \mathrm{~mm}$ at the base, $25 \mathrm{~mm}$ of height and volume of $15 \mathrm{~cm}^{3}$ (Magini; Marzola, 2008).

With the loss of dental elements, the local physiological stimuli, provided by the teeth and periodontal ligaments that hold the alveolar bone, disappear starting a degenerative, chronic, progressive, incurable and cumulative bone resorption. This resorption is a complex, multifactorial and irreversible process, being faster in the first months, and continuing throughout the life of the individual (Bartee, 2001; Marzola, 2002; Mazzonetto et al., 2005; López-Roldán et al., 2009; Gupta et al., 2010; Mizutani et al., 2010).

According to Kenezovié-Zlatarié et al. (2002), due to extensive bone loss, the denture loses support, there is no prosthesis retention and stability are compromised. For this, the knowledge and respect for the anatomical prosthetic structures, is of extreme importance for the correct adaptation of the prosthesis, seeking to provide stability, retention and comfort during use. Contributing to them, Astudillo Silva said that the knowledge of the morphology of the bone defect is important and should be considered for the selection of a rehabilitation method for increasing the residual alveolar ridge in the maxilla.
During the process of resorption of the alveolar process is common to note insufficient bone quantity (thickness and / or height) for the installation of osseointegrated implants in the anterior maxilla (Magini; Astudillo Silva). The lack of bone volume may also result in an incorrect positioning of the implants due to improper installation on the angle that compromise the aesthetic result in hygiene problems and may lead to loss of the implants (Marzola, 2008; Astudillo Silva).

Assunção et al. (2004) claim that the imbalance of stomatognathic system, provided by the loss of teeth, also causes changes in the gum and muscular tissue, and in the temporomandibular joints, resulting directly in chewing and speech, causing discomfort and difficulty in performing these activities, as well as aesthetic and patient comfort damage. Silva et al. (2007) reported that combined with this, the social interaction that can also be damaged for these individuals, since they will be ashamed to smile and talk because of the precarious situation of the mouth.

Thus, the data obtained in this study agree with the authors of several studies cited above, does demonstrate the anatomical changes that occur in the alveolar bone ridge of the maxillary bone after the loss of teeth, has consequences for the aesthetics, quality of life and rehabilitation through prosthetics and dental implants.

In conclusion, as the tooth loss occurs, irreversible anatomical changes take place in the maxillary bone, occurring alveolar bone resorption process, confirmed by 
comparison of measurements between anatomical accidents of toothed and toothless maxillas of human skulls, which affects the aesthetics and quality of life of the indi- vidual and should be taken into account in planning and making of dentures and the installation of osseointegrated implants.

DE OLIVEIRA, J. B.; DE ALMEIDA, A. N. C. L.; LINS, C. C. S. A.; JÚNIOR, A. A. A. \& SEIXAS, Z. A. Mediciones antropométricas en maxilares con y sin dientes de humanos y sus consecuencias en la reabsorción ósea alveolar. Int. J. Morphol., 30(3):1173-1176, 2012.

RESUMEN: Este estudio propuso medir y comparar las medidas antropométricas entre los maxilares con y sin dientes. Fueron utilizados 26 cráneos humanos, 13 maxilares con dientes y 13 sin dientes. Las mediciones fueron realizadas a ambos lados por dos evaluadores entre las distancias del reborde alveolar (RA): a la espina nasal anterior (ENA), al canal incisivo (CI) y a lo foraámenes palatinos mayor (FPMA) y menor (FPME). Los datos mostraron que la media de las mediciones fueron proporcionalmente mayores en las maxilas con dientes, para todas las mediciones en cualquiera de los evaluadores. El RA-ENA ( $p=0,001)$, AR-CI ( $p=0,006)$, RA-APMA derecho ( $p=0,001)$ y RA-APMA izquierdo ( $p<0,001)$ y RA-APME en ambos lados $(\mathrm{p}=0,001)$, comprobando la existencia de diferencias significativas entre los dos tipos de maxila. Fue verificado que a partir de la pérdida dental ocurren irreversibles cambios anatómicos en el maxilar, que deben ser considerados en el diseño y fabricación de prótesis e implantes osteointegrados.

PALABRAS CLAVE: Anatomía; Maxilar; Prótesis total; Pérdida ósea alveolar; Implantación dental.

\section{REFERENCES}

Assunção, W. G.; Shiwa, M.; Gennari Filho, H.; Goiato, M. C.; Barbosa, D. B. \& Tabata, L. F. Para-prosthetic anatomy: importance in complete dentures. Rev. Odontol. Araçatuba, 25(1):57-64, 2004.

Astudillo Silva, M. A. Surgical solutions for the treatment of atrophic maxillae bone grafts and zygomatic implants literature review and clinical case presentation. Monografia Especialização em Cirurgia e Traumatologia BucoMaxiloFacial. Bauru, Associação Paulista de Cirurgiões-Dentistas (APCD), 2010. p.46.

Bartee, B. K. Extraction site reconstruction for alveolar ridge preservation. Part 1: Rationale and materials selection. J. Oral Implantol., 27(4):187-93, 2001.

Gupta, A.; Tiwari, B.; Goel, H. \& Shekhawat, H. Residual ridge resorption: a review. Indian J. Dent. Sci., 2(2):7-11, 2010.

Jorge, T. M.; Bassi, A. K.; Yarid, S. D.; Silva, H. M.; Silva, R. P. R.; Caldana, M. L. \& Bastos, J. R. M. Relation between tooth loss and chewing, swallowing and speech complaints in adults. Rev. CEFAC, 11(13):391-7, 2009.

Kenezovié-Zlatarié, D.; Celebié, A. \& Lazié, B. Resorptive Changes of Maxillary and Mandibular Bone Structures in Removable Denture Wearers. Acta Stomatol. Croat., 36(2):261-5, 2002.

López-Roldán, A.; Santolaya-Abad, D. S.; Gregori-Bertomeu, I. G.; Gómez-Castillo, E. G. \& Selva-Otaolaurruchi, E. S. Bone resorption processes in patients wearing overdentures. A 6-years retrospective study. J. Clin. Exp. Dent., 1(1):24-30, 2009.

Marzola, C. Cirurgia Pré-Protética. $3^{\text {a }}$ ed. São Paulo, Pancast, 2002. p.412.

Marzola, C. Fundamentos de Cirurgia e Traumatologia BucoMaxiloFacial. $1^{\text {a }}$ Ed. São Paulo, BigForms, 2008. p.3250.

Magini, R. S. Enxertos ósseos no seio maxilar. Estética e função. $1^{\text {a }}$ ed. São Paulo, Santos, 2006. p.330.
Mandarim-De-Lacerda, C. A. Métodos Quantitativos em Morfologia. Rio de Janeiro, UERJ, 1995. p.131.

Mizutani, F. S.; Nagem Filho, H.; Valiense, H.; Carbonari, M. J. \& Campi Júnior, L. Matrix osseoindutor for alveolar ridge augmentation. FULL Dent. Sci., 1(2):112-6, 2010.

Mazzonetto, R.; Maurette, M. A.; Maurette, P. E. \& Torrezan, J. F. R. Distracção Osteogénica para a Reconstrução de Rebordos Alveolares Atróficos. Rev. Port. Estomatol. Med. Dent. Cir. Maxilofac., 46(4):212-20, 2005.

Paganini-Hill, A. Hormone Therapy and Oral Health. Menopause Manage., 16(3):31-40, 2007.

Ribeiro, D. G.; Silva, M. M.; Nogueira, S. S. \& Arioli Filho, J. N. A Saúde Bucal na Terceira Idade. Salusvita, 28(1):101-11, 2009.

Silva, P. V.; Santana, S. R. F.; Almeida, E. C. B.; Araújo, A. C. S.; Cimões, R. \& Gusmão, E. S. The dental number influence on daily performance. RFO UPF, 12(3):13-7, 2007.

Unfer, B.; Braun, K.; Silva, C. P. \& Pereira Filho, L. D. Self-perception of the loss of teeth among the elderly. Interface (Botucatu), 10(19):217-26, 2006.

Zanon, L. P. Maxillary total osteotomies study - Le Fort I: Literature review. Monografia Especialização em Cirurgia e Traumatologia BucoMaxiloFacia. Bauru, Associação Paulista de CirurgiõesDentistas (APCD), 2009. p.33.

Correspondence to:

Carla Cabral dos Santos Accioly Lins

Rua Manuel de Carvalho, 310, Apt. 303

Aflitos, Recife - PE. CEP: 52050-370

BRAZIL

Email: cabralcarla1@hotmail.com

Received: 14-11-2011

Accepted: 17-04-2012 